\title{
Assessing the Patterns of Youth Use of Social Media and their Parental Oversight
}

\author{
Samia E. Khaton ${ }^{1}$, Fatma El-Sayed Soliman ${ }^{2}$ \\ ${ }^{1,2}$ Assistant Professors of Community Health Nursing, Faculty of Nursing Tanta university, \\ Egypt
}

\section{Abstract}

Background: Social media plays a crucial role in the lives of networked adolescents and take up a great deal of their time. Parental oversight or monitoring is essential at this period to protect against inaccurate, inappropriate or unsafe content and contacts. Aim of the study: Was to assess the patterns of youth use of social media and parental oversight for them. Study design: Descriptive research design was used in this study. Setting: This study was conducted in all governmental 15 secondary schools in Tanta city. Subjects: A convenience sample of 1000 students $\left(6.12 \%\right.$ ) (483 boys and 517 girls) from $1^{\text {st }}$ grade to $3^{\text {rd }}$ grade of 15 secondary schools were selected by proportional allocation method. Tool of data collection: Structured questionnaire sheet that consisted of five parts: socio-demographic data; availability of social media and internet media; causes of using social media; patterns of using social media; parents' oversight to their adolescents' social media activities. Results: The results of this study showed that $78.1 \%$ and $76.2 \%$ of studied males and females respectively use social media for communication and more than half of them use it since more than three years for about 3 times per day. The majority (84.1\% and 71.4\%) of males and females, their parents did not oversight them. Conclusion: The majority of the studied adolescents use social media for communication since more than three years for about 3 times per day. Lack of parental oversight was prevalent among the studied subjects while using social media. Recommendations: It is essential to design health educational programs to preparatory and secondary school students to improve their inappropriate use of social media and to prevent its hazards. Educate the parents and the families about the importance of their oversight and follow up their adolescents during using social media.

Keywords: Adolescents, Patterns, Social Media, Parental oversight 


\section{Introduction}

Adolescence is a time of self-disclosure and conflict to find a balance between autonomy and connectedness. It is a period in which an individual face major physical, psychological, body and brain changes. It may begin as early as age 8 and extend until age 24. Adolescents represent one fifth of the global population. In Egypt, according to Egypt Demographic profile 2018, the age group of 15-24 years represents $18.94 \%$ of the total population $^{(1,2)}$.

Today's adolescents have unprecedented access to modern technology and use them in expected and unexpected ways. They spend many hours a day using technology ${ }^{(3)}$. Adolescents are among the highest users of technology and are typically early adaptors of new technologies including internet, mobile phones, social media and other devices ${ }^{(4)}$.

Social media has a diversity of functions and structures of applications. It takes on many different forms, involving both webbased and mobile technologies including internet forums, instant messaging (IM), social networking services (SNS) and micro blogs. Today, new applications in social media such as Facebook, IM, blogs, Twitter, YouTube and online games are well accepted as the preferred tools for communication among adolescents. The most six main groups of social media are social networks, wikis, content communities, blogs, micro-blogs and forums. This categorization of social media forms because of its interpersonal and user-generated nature "two way interaction" ${ }^{(5)}$.

In Britain 2017, and United States 2016, an estimated $85 \%$ of internet users aged 16 years and more than $90 \%$ of $16-29$ year olds had the highest usage of social networking sites. Problematic internet use among adolescents is between $4 \%$ and $8 \%$ up to $8.5 \%$ of US youth 8 to 18 years of age meet criteria for internet gaming disorder ${ }^{(6-8)}$. Also, active users of social media in Arab region in 2015, was aged $\geq 15$ years who use at least one social media channel ${ }^{(9)}$.

Egypt had about a quarter of total Facebook users in Arab region and $75 \%$ of total Arab country Facebook users were youth (15-29) years ${ }^{(10,11) .}$ In Egypt 2015, Panel Survey of Young People that compare between years 2009 and 2014 found that, compared to before the revolution, internet and media usage among young people aged 15-19 years quickly growing from $7.5 \%$ in 2009 to $25 \%$ in $2014^{(12)}$. There were 42.00 million social media users in Egypt in January 2020. The number of social users in Egypt increased by 2.9 million $(+7.3 \%)$ between April 2019 and January $2020^{(13)}$. 
Problematic internet use among a sample of Egyptian adolescents revealed that $65.6 \%$ were having internet addiction, $61.3 \%$ were gaming addicts, and $92.8 \%$ Facebook addicts ${ }^{(14)}$.

While media use is an integral part of the daily life of adolescents, there are a number of risks associated with social media use, specifically, negative effects on mental health, cyber bullying, texting/sexting, dangers of sexual solicitation and exposure to problematic and illegal content and privacy violations. The categories of risks teenagers face on a social media are broadly the same as those they face on the internet in general ${ }^{(15,16)}$.

With millions of teenagers on the Internet, millions of parents are trying to understand what their teens are doing and why. Understanding how technology use impacts teens' learning, growth, and social development is critical for their health and wellbeing and for the welfare of the family. Yet, balancing parent authority with teen privacy and autonomy is difficult. Proliferating internet-accessible media have altered the home context, raising questions about parental influence on youth computer/internet use. Greater general parental oversight of adolescents predicted less teen engagement in networking site use ${ }^{(17)}$.

Parents should watch what their teens watch so they can talk about what they're seeing on their screens. They know their teens best, so they are the best judge of what they can handle. They can use a number of programs and apps to monitor teens' social media accounts which alert parents to any inappropriate language or photos and give detailed reports of teens browsing history and how much time they spent online and on each site ${ }^{(18)}$.

Parents' talking to their teens about safe online practices is a teachable moment. These kinds of discussions can provide important benefits of instilling ethical behavior. Teens learn how to develop responsible online practices and that their behavior towards others may influence the way others feel about themselves and how they feel about the teen. Parents should ensure that their teens demonstrates their ability to follow the rules, meet their expectations, and understand the consequences of unacceptable behaviors $^{(19)}$.

School health nurse has an important role of helping students to change their life style to optimal health through increasing awareness, change risk behaviors and support good health practice. It's important to note common misconceptions among students regarding the use of social media $^{(20,21)}$.

In addition, she can educate the adolescents and their parents about protective measures and about safe 
environment as keep power supply outside bedroom and decrease the exposure at night ${ }^{(22)}$. Furthermore, she can teach the parents to be aware of their teens' online through frequent track of their online behavior. Tell them to protect privacy by keep their personal information online and password secret (23). Moreover, school health nurse must provide the parents with clear instruction to observe their adolescents if bullied as becomes sad, angry or appears anxious when receiving a text or email or avoid discussions or is secretive about cell phone activities ${ }^{(24)}$.

\section{The aim of the study}

The aim of this study was to assess the patterns of youth use of social media and their parental oversight.

\section{Research Questions}

1-What are the patterns of youth use of social media?

2- To what extent the parents' oversight their adolescents during using social media? 3- What are the factors that may affect parental oversight for their youth during using social media?

\section{Subjects and Method}

\section{Study Design}

Descriptive research design was used in this study.

\section{Settings}

This study was conducted in all governmental general secondary schools in
Tanta city. Their number was 15 schools representing the two educational zones in Tanta city, east and west zones (nine schools of east educational zoon and six schools of west zoon).

\section{Subjects}

A total sample of 1000 students (483 boys and 517 girls) that represent $6.12 \%$ of the total students from $1^{\text {st }}$ grade to $3^{\text {rd }}$ grade of secondary schools in both east and west educational zones were conveniently selected by proportional allocation method as shown in the table: 


\begin{tabular}{|c|c|c|c|c|c|c|}
\hline \multirow{2}{*}{ Educational zoon } & \multicolumn{2}{|c|}{$\begin{array}{c}\text { Total No. of } \\
\text { students }\end{array}$} & \multirow{2}{*}{ Total } & \multicolumn{2}{|c|}{$\begin{array}{c}\text { The selected } \\
\text { 6.12\% of student }\end{array}$} & \multirow{2}{*}{ Total } \\
\cline { 2 - 6 } & Boys & Girls & & Boys & Girls & \\
\hline East educational zoon & 4374 & 3654 & 8028 & 267 & 223 & 490 \\
\hline West educational zoon & 3485 & 4809 & 8294 & 216 & 294 & 510 \\
\hline Total & 7859 & 8463 & 16322 & 483 & 517 & 1000 \\
\hline
\end{tabular}

\section{Tools of the study}

A structured questionnaire sheet was used in this study to collect necessary data. It was developed by the researchers based on a thorough review of literatures (25-28). The tool comprises of 22 questions divided into five main parts: -

Part (1): Socio-demographic data of the study subjects (13) questions:

Which covered data about sex, age, grade, parents' education \& occupation, family income, with whom he/ she live, the number of family members. birth order, and daily expense.

Part (2): Availability of social media and internet media (1) question:

Which assessed the accessibility of internet and social media through the assessment of the availability of different devices as mobile phones, laptop, personal computer or through cyber and net café.

Part (3): Causes of using social media by the study subjects (1) question:

Which covered data about the students' different causes of connecting to internet and social media such as: communication with relatives and friends, read blogs and news, discuss current events, for interesting with time, share photos and entertainment, learning and search, escape from reality, electronic shopping and others.

Part (4): Patterns of using social media by the students (4) questions:

Such as the age of starting use the social media for first time, ability of using social media without help, frequency of using social media / day, and duration spending / session,

Part (5) Parents oversight for their adolescents and causes for lacking of oversight (3) questions:

Included asking if parents oversight their adolescents use of social media, their awareness of their adolescents social media activities and causes of lack of parental oversight.

\section{Method}

1. Before conducting the study, an official permission was obtained from 
the dean of the faculty of nursing to the manager of the educational administration in Gharbia governorate and then to the managers of selected schools in Tanta city.

\section{Ethical considerations:}

- The consent of ethical committee of Faculty of Nursing, Tanta University was obtained to conduct the study.

- Informed consent was obtained from all selected students after providing appropriate explanation about the purpose of the study.

- Every student was ensured about the privacy and confidentiality of all information collected.

\section{Data collection procedure:}

\section{- Developing the tool:}

Structured questionnaire sheet was developed by the researchers based on relevant literature reviewed ${ }^{(25-28)}$. Then the study tool was tested for face and content validity by a jury of five expertise in the field of community health nursing.

\section{- The pilot study:}

A pilot study was carried out on $10 \%$ of the students ( 100 students from the three grads) for testing the clarity and applicability of the study tool and to estimate the length of time needed to fulfill data collection from each student as well as to identify any obstacles or problems in data collection. Those students were excluded from study sample.
- Based on the result of the pilot study, study tool was tested for its reliability using Cronbach's Alpha test based on standardized items. It was (0.865) which indicated highly reliable tool.

-Field work:

- The data were collected by the researchers over a period of two months starting from 15 October until 15 December in the academic year (2019/2020).

- Each student was informed about the purpose and benefits of the study at the beginning of the interview.

- One class from each grade (first, second and third) in each school was selected randomly to reach the required number.

- Each student was asked to fill the questionnaire by himself / herself in the presence of the researcher for providing any clarification or explanation as needed.

- The tool was administered to all students at their schools at an appropriate time as coordinated with the director of each school.

\section{Data analysis}

The collected data was organized, tabulated and statistical analyzed using SPSS software statistical computer package version 23. For quantitative data, the range, mean and standard deviation were calculated. For qualitative data, 
comparison was done using Chi-square test $\left(\chi^{2}\right)$. Correlation between variables was evaluated using Pearson's and Spearman's correlation coefficient (r). A significance was adopted at level $\mathrm{P}<0.05$ for interpretation of results of tests of significance. However, a strong significance was adopted at level $\mathrm{P}<0.01$.

\section{Difficulties}

The sample collection from both boys and girls students in $3^{\text {rd }}$ grade was difficult because they were not at schools and so they were reached through private classes.

\section{Results}

Table (1) represents the distribution of the studied students according to their sociodemographic data. It shows that, about three quarters $(70 \%$ and $75.2 \%)$ of the studied boys and girls were in the age group of $14<17$ years respectively. Their age ranged between 15-20 years for boys and 14-19 years for girls with a mean age of $(16.92 \pm 1.028)$ and $(16.67 \pm 1.075)$ among boys and girls respectively. There was no significant difference found between age of boys and girls ( $\mathrm{P}=0.062$ ).

Regarding the studied students' educational grade, the table shows that nearly one third (33.5\%) of both boys and girls were from first grade, second grade $(32.5 \%$ and $33.7 \%)$ and third grade $(33.5 \%$ and $32.9 \%)$ respectively. No significant difference was found between grade of boys and girls ( $P$ $=0.964)$.
The table shows also that the majority of studied boys and girls were lived with their parents and siblings (87.8\% and 85.9\%) respectively with no significance difference $(\mathrm{P}=0.063)$. Nearly three quarters $73.5 \%$ of studied boys compared to $81.4 \%$ of studied girls had five or more family members and $22.6 \%$ of boys compared to $15.1 \%$ of girls had four family members. There was a high significance difference between family members of boys and girls $(\mathrm{P}=0.008)$.

Concerning the birth order of the studied students this table reveals that, less than half of studied boys and girls were the oldest $(43.1 \%$ and $44.7 \%$ ) respectively with no significance differences between boys and girls $(\mathrm{P}=0.276)$. In relation to daily expense the table shows that $43.1 \%$ of studied boys compared to about half of studied girls (49.3\%) had daily expense from five to ten pounds and $16.6 \%$ of boys compared to $11.2 \%$ of girls had $>10$ pounds daily expense with a significance difference $(\mathrm{P}=0.026)$.

Table (2) shows the distribution of the studied students according to their parents' socio-demographic characteristics. Concerning father's education, more than one third $(38.3 \%$ and $37.1 \%)$ of the studied boys their fathers had secondary education and university education respectively. While, more than two fifths $(43.5 \%)$ of the studied girls their fathers had university 
education / post university and about one third $(32.7 \%)$ of them their fathers had secondary education. Significant difference was found between boys and girls in relation to their fathers' education $(\mathrm{P}$ $=0.042$ ). As for mother's education, the table illustrates also that about one third (35.4\% and $30.2 \%)$ of the studied boys their mothers had secondary education and university education / post respectively. While, more than one third $(37.1 \%)$ of the studied girls their mothers had university education / post and about one third $(32.7 \%)$ of them their mothers had secondary education. No a significant differences were found between boys and girls mothers' education ( $\mathrm{P}=0.141)$.

In relation to the father's occupation, the majority of fathers of both boys and girls were worked $(93.8 \%$ and $91.9 \%)$ respectively. While, about two thirds (62.1\% and $67.5 \%)$ of both boys' and girls' mothers were housewives respectively. No significant differences were found also between boys' and girls' fathers and mothers occupation ( $\mathrm{P}=0.242$ and 0.074$)$ respectively. Furthermore, the table illustrates that more than half $(58.2 \%)$ of studied boys and nearly two thirds (63.8\%) of studied girls had enough family income. No significant differences were found between family income of both boys and girls $(\mathrm{P}=0.187)$
Table (3) and figure (1) represents the distribution of the studied students regarding accessibility of social media and causes for using it. The table and figure show that, more than three quarters $(78.1 \%$ and $76.2 \%$ ) of both boys and girls had mobile phones respectively and nearly half (48.0\% and $45.6 \%$ )of them had computers respectively. Furthermore, about one quarter $(27.3 \%$ and $24.8 \%)$ of both boys and girls had laptops or tablets respectively. Indeed, cyber \& net café were available for $15.3 \%$ of the studied boys and for only $4.6 \%$ of the studied girls. There was a high statistically significant difference between boys and girls in relation to availability of cyber \& net café as a social media $(\mathrm{P}<0.01)$.

Concerning the goal of using social media, the table indicates that the majority $(86.5 \%$ and $83.8 \%$ ) of both boys and girls respectively used social media for communication with relatives /friends. Also, it was obvious that, more than half $(51.1 \%$ and $56.9 \%)$ of both boys and girls respectively and about two fifths (38.1\% and $44.9 \%$ ) of them respectively used the social media for learning / search or for share photos /entertainment respectively. The table reveals that about one third $(33.5 \%, 33.7 \%$ and $31.3 \%)$ of studied boys respectively and of studied girls $(36.6 \%$, $28.6 \%$ and $25.1 \%$ ) respectively used the social media for read blogs / news, discuss 
current events and for interesting with time respectively. The table also shows that less than one quarter $(18.0 \%$ and $22.2 \%)$ of both boys and girls respectively used the social media as a way to escape from reality. The difference between boys and girls was significance only in relation to using social media as for interesting with time and share photos and entertainment $(\mathrm{P}$ $=0.031$ and 0.03 ) respectively.

Table (4) represents the distribution of the studied students regarding patterns of using social media. The table reveals that slightly more than one half $(51.1 \%$ and $54.7 \%)$ of the studied boys and girls respectively had starting to use social media for the first time since more than three years. Regarding the ability to use social media without help, it was clear that the highest frequencies of both boys and girls were excellent or good in using social media $(43.3 \%$ and $44.7 \%)$ and $(32.3 \%$ and $31.1 \%$ ) respectively while, only $3.7 \%$ of boys and $1.4 \%$ of girls don't use social media.

In relation to the frequency of using social media / day, the table reveals that more than half of boys (52.8\%) and about two thirds of girls $(60.7 \%)$ used social media 13 times/ day. While, more than one fifth of studied boys and girls used social media > 5 times /day $(24.0 \%$ and $20.5 \%)$ respectively.
Concerning the duration of spending / session, the table illustrates that $11.8 \%$ of boys and $17.6 \%$ of girls spent $>2$ hours using social media each time. Indeed, slightly less than one quarter $(22.6 \%$ and $23.8 \%$ ) of both boys and girls spent 5-15 minutes on using social media each time respectively. Significant statistical differences were observed only among boys and girls in relation to the frequency of using social media / day $(\mathrm{P}=0.039)$ and the duration of spending / session of using social media $(\mathrm{P}<0.01)$.

Table (5) represents the distribution of the studied students regarding their parents' oversight on using social media by them. The table reveals that there was no parental oversight for the majority of boys $(84.1 \%)$ and for less than three-quarters of girls (71.4\%) during their use of social media. However, girls were more mentored than boys. Highly significant differences were observed $(\mathrm{P}<0.01)$. Moreover, the table shows that $92.1 \%$ of males and $67.9 \%$ females reported that their parents were not aware of their online social networking activities.

Concerning the causes of lack of parents' oversight or oversight, about half of the studied boys (50.9\% and $48.4 \%$ ) reported that this may be due to the parents' preoccupation and parents' confidence in their adolescents respectively. 
While, (52.2\% and $42.6 \%)$ of the studied girls reported that lack of parents oversight may be related to the parents' confident in their adolescents and preoccupation respectively. The table shows also that (32.5\% and $23 \%)$ of studied boys and girls respectively reported that lack of parents oversight may be due to the ignorance of using social media. About one quarter (24.0\%) of boys and $18 \%$ of girls reveals lack of oversight to lack of awareness of parents about hazards of using social media.

High statistically significant differences were found between studied boys and girls regarding causes of lacking of parents oversight including parents preoccupation, unawareness of hazards of social media and ignorance of using social media as a causes of lack of oversight $(\mathrm{P}=0.008$, 0.019 and 0.001 ) respectively.

Table (6) shows the correlation between socio-demographic data of the studied students and their parents and their patterns of using social media. The table illustrate that there was a significant negative correlation between students' sex and number of family members and frequency of using social media / day ( $\mathrm{P}=0.018$ and 0.007) respectively. While, a significant positive correlation was found between students' birth order and frequency of using social media / day $(\mathrm{P}=0.045)$. Also, there was a positive correlation between grade of students and starting to use social media for first time $(\mathrm{P}<0.01)$.

Furthermore, the table shows that there was a highly positive correlation between father's and mother's education and all items of patterns of using social media as starting to use social media for first time, ability of using social media without help, frequency of using social media /day and duration /session $(\mathrm{P}<0.01)$.

In addition, a highly negative correlation was found between father's occupation and ability of using social media without help by the students $(\mathrm{P}=0.001)$. While, there was a highly negative correlation between mother's occupation and all items of patterns of using social media as starting to use social media for first time, ability of using social media without help, frequency of using social media / day and duration / session $(\mathrm{P}<0.01)$.

As for daily expense, the table illustrates that there was a highly positive correlation between it and all items of patterns of using social media as starting to use social media for first time, ability of using social media without help, frequency of using social media / day and duration / session ( $\mathrm{P}$ $<0.01)$.

Regarding family income, the table shows that there was a highly positive correlation between family enough income that can be saved and all items of patterns of using social media as starting to use social media 
for first time, ability of using social media without help, frequency of using social media / day and duration / session $(\mathrm{P}=<$ 0.01). On the other hand, a highly negative correlation was fond between those who haven't enough income and all items of using social media patterns as starting to use social media for first time, ability of using social media without help, frequency of using social media / day and duration / session $(\mathrm{P}=<0.01)$. The table also reveals that there was a negative correlation between family enough income and frequency of using social media / day and duration / session $(\mathrm{P}=0.015$ and 0.049) respectively. 
Table (1): Distribution of the studied students according to their Socio-demographic data

\begin{tabular}{|c|c|c|c|c|c|}
\hline \multirow{4}{*}{ Students' socio-demographic data } & \multicolumn{5}{|c|}{ The studied students $(n=1000)$} \\
\hline & \multicolumn{2}{|c|}{$\begin{array}{c}\text { Boys } \\
(\mathrm{N}=\mathbf{4 8 3})\end{array}$} & \multicolumn{2}{|c|}{$\begin{array}{c}\text { Girls } \\
(\mathrm{N}=\mathbf{5 1 7})\end{array}$} & \multirow{3}{*}{$\begin{array}{l}\chi^{2} \\
\mathbf{P}\end{array}$} \\
\hline & No. & $\%$ & No. & $\%$ & \\
\hline & & & & & \\
\hline $\begin{array}{c}\text { Age in years: } \\
\text { - } 14<17 \\
\text { - } \quad \geq 17-20\end{array}$ & $\begin{array}{l}338 \\
145\end{array}$ & $\begin{array}{l}70.0 \\
30.0\end{array}$ & $\begin{array}{l}389 \\
128\end{array}$ & $\begin{array}{c}75.2 \\
24.8\end{array}$ & \multirow{2}{*}{$\begin{array}{l}3.484 \\
0.062\end{array}$} \\
\hline $\begin{array}{l}\text { Range } \\
\text { Mean } \pm \text { SD }\end{array}$ & \multicolumn{2}{|c|}{$\begin{array}{l}(15-20) \\
16.92 \pm 1.028\end{array}$} & \multicolumn{2}{|c|}{$\begin{array}{l}(14-19) \\
16.67 \pm 1.075\end{array}$} & \\
\hline $\begin{array}{l}\text { Grade } \\
\text { - First } \\
\text { - Second } \\
\text { - } \text { Third }\end{array}$ & $\begin{array}{l}162 \\
159 \\
162\end{array}$ & $\begin{array}{l}33.5 \\
33 \\
33.5\end{array}$ & $\begin{array}{l}173 \\
174 \\
170\end{array}$ & $\begin{array}{l}33.5 \\
33.6 \\
32.9\end{array}$ & $\begin{array}{l}0.074 \\
0.964\end{array}$ \\
\hline $\begin{array}{l}\text { Live with } \\
\text { - Parents and siblings } \\
\text { - Father and siblings only } \\
\text { - Mother and siblings only } \\
\text { - Siblings only } \\
\text { - One of the relatives } \\
\text { - Others }\end{array}$ & $\begin{array}{l}424 \\
22 \\
30 \\
3 \\
4 \\
0\end{array}$ & $\begin{array}{l}87.8 \\
4.6 \\
6.2 \\
0.6 \\
0.8 \\
0.0\end{array}$ & $\begin{array}{l}444 \\
15 \\
48 \\
3 \\
2 \\
5\end{array}$ & $\begin{array}{l}85.9 \\
2.9 \\
9.2 \\
0.6 \\
0.4 \\
1.0\end{array}$ & $\begin{array}{l}10.462 \\
0.063\end{array}$ \\
\hline $\begin{array}{l}\text { No of family members including student } \\
\text { - } 3 \text { members } \\
\text { - } 4 \text { members } \\
\text { - } \geq 5 \text { member }\end{array}$ & $\begin{array}{l}19 \\
109 \\
355\end{array}$ & $\begin{array}{l}3.9 \\
22.6 \\
73.5\end{array}$ & $\begin{array}{l}18 \\
78 \\
421\end{array}$ & $\begin{array}{l}3.5 \\
15.1 \\
81.4\end{array}$ & $\begin{array}{l}9.635 \\
0.008 * *\end{array}$ \\
\hline $\begin{array}{l}\text { Birth order } \\
\text { - The oldest } \\
\text { - Middle } \\
\text { - The youngest }\end{array}$ & $\begin{array}{l}208 \\
174 \\
101\end{array}$ & $\begin{array}{l}43.1 \\
36.0 \\
20.9\end{array}$ & $\begin{array}{l}231 \\
163 \\
123\end{array}$ & $\begin{array}{l}44.7 \\
31.5 \\
23.8\end{array}$ & $\begin{array}{l}2.572 \\
0.276\end{array}$ \\
\hline $\begin{array}{l}\text { Daily expense } \\
\text { - } \quad<5 \text { pounds } \\
\text { - } 5-10 \text { pounds } \\
\text { - }>10 \text { pounds }\end{array}$ & $\begin{array}{l}195 \\
208 \\
80\end{array}$ & $\begin{array}{l}40.4 \\
43.1 \\
16.6\end{array}$ & $\begin{array}{l}204 \\
255 \\
58\end{array}$ & $\begin{array}{l}39.5 \\
49.3 \\
11.2\end{array}$ & $\begin{array}{l}7.334 \\
0.026 *\end{array}$ \\
\hline
\end{tabular}

* Significant at $\mathrm{P}<0.05$. ** Significant at $\mathrm{P}<0.01$. 
Table (2): Distribution of the studied students according to their parents' sociodemographic data

\begin{tabular}{|c|c|c|c|c|c|}
\hline \multirow{3}{*}{ Parents' socio-demographic data } & \multicolumn{5}{|c|}{$\begin{array}{l}\text { The studied students } \\
\qquad(\mathrm{n}=1000)\end{array}$} \\
\hline & \multicolumn{2}{|c|}{$\begin{array}{c}\text { Boys } \\
(\mathrm{N}=483)\end{array}$} & \multicolumn{2}{|c|}{$\begin{array}{c}\text { Girls } \\
(\mathrm{N}=\mathbf{5 1 7})\end{array}$} & \multirow{2}{*}{$\begin{array}{l}\chi^{2} \\
\mathbf{P}\end{array}$} \\
\hline & No. & $\%$ & No. & $\%$ & \\
\hline $\begin{array}{l}\text { Father's education } \\
\text { - Illiterate or reads and writes } \\
\text { - Elementary education } \\
\text { - Secondary education } \\
\text { - University education / post }\end{array}$ & $\begin{array}{l}20 \\
99 \\
185 \\
179\end{array}$ & $\begin{array}{l}4.1 \\
20.5 \\
38.3 \\
37.1\end{array}$ & $\begin{array}{l}11 \\
112 \\
169 \\
225\end{array}$ & $\begin{array}{l}2.1 \\
21.7 \\
32.7 \\
43.5\end{array}$ & $\begin{array}{l}8.228 \\
0.042 *\end{array}$ \\
\hline $\begin{array}{l}\text { Mother's education } \\
\text { - Illiterate or reads and writes } \\
\text { - Elementary education } \\
\text { - Secondary education } \\
\text { - University education / past }\end{array}$ & $\begin{array}{l}38 \\
128 \\
171 \\
146\end{array}$ & $\begin{array}{l}7.9 \\
26.5 \\
35.4 \\
30.2\end{array}$ & $\begin{array}{l}37 \\
119 \\
169 \\
192\end{array}$ & $\begin{array}{l}7.2 \\
23.0 \\
32.7 \\
37.1\end{array}$ & $\begin{array}{l}5.464 \\
0.141\end{array}$ \\
\hline $\begin{array}{l}\text { Father's occupation } \\
\text { - Worked } \\
\text { - Not worked }\end{array}$ & $\begin{array}{l}453 \\
30\end{array}$ & $\begin{array}{l}93.8 \\
6.2\end{array}$ & $\begin{array}{l}475 \\
42\end{array}$ & $\begin{array}{l}91.9 \\
8.1\end{array}$ & $\begin{array}{l}1.367 \\
0.242\end{array}$ \\
\hline $\begin{array}{l}\text { Mother's occupation } \\
\text { - Worked } \\
\text { - House wife }\end{array}$ & $\begin{array}{l}183 \\
300\end{array}$ & $\begin{array}{l}37.9 \\
62.1\end{array}$ & $\begin{array}{l}168 \\
349\end{array}$ & $\begin{array}{l}32.5 \\
67.5\end{array}$ & $\begin{array}{l}3.188 \\
0.074\end{array}$ \\
\hline $\begin{array}{l}\text { Family income } \\
\text { - Enough } \\
\text { - Enough and save } \\
\text { - Not enough }\end{array}$ & $\begin{array}{l}281 \\
138 \\
64\end{array}$ & $\begin{array}{l}58.2 \\
28.6 \\
13.3\end{array}$ & $\begin{array}{l}330 \\
128 \\
59\end{array}$ & $\begin{array}{l}63.8 \\
24.8 \\
11.4\end{array}$ & $\begin{array}{l}3.357 \\
0.187\end{array}$ \\
\hline
\end{tabular}

* Significant at $\mathrm{P}<0.05$. 
Table (3): Distribution of the studied students regarding accessibility of social media and causes for using it

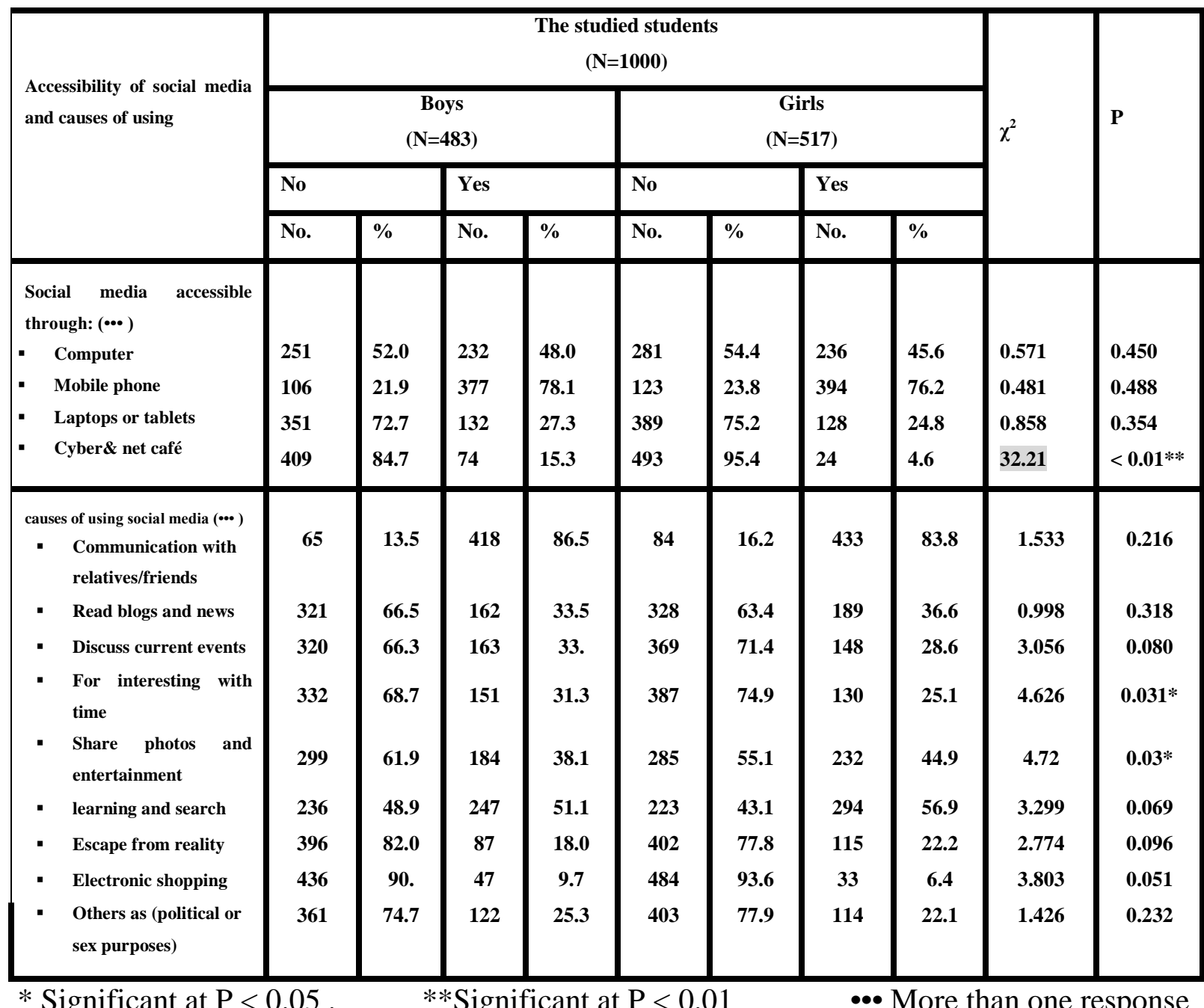

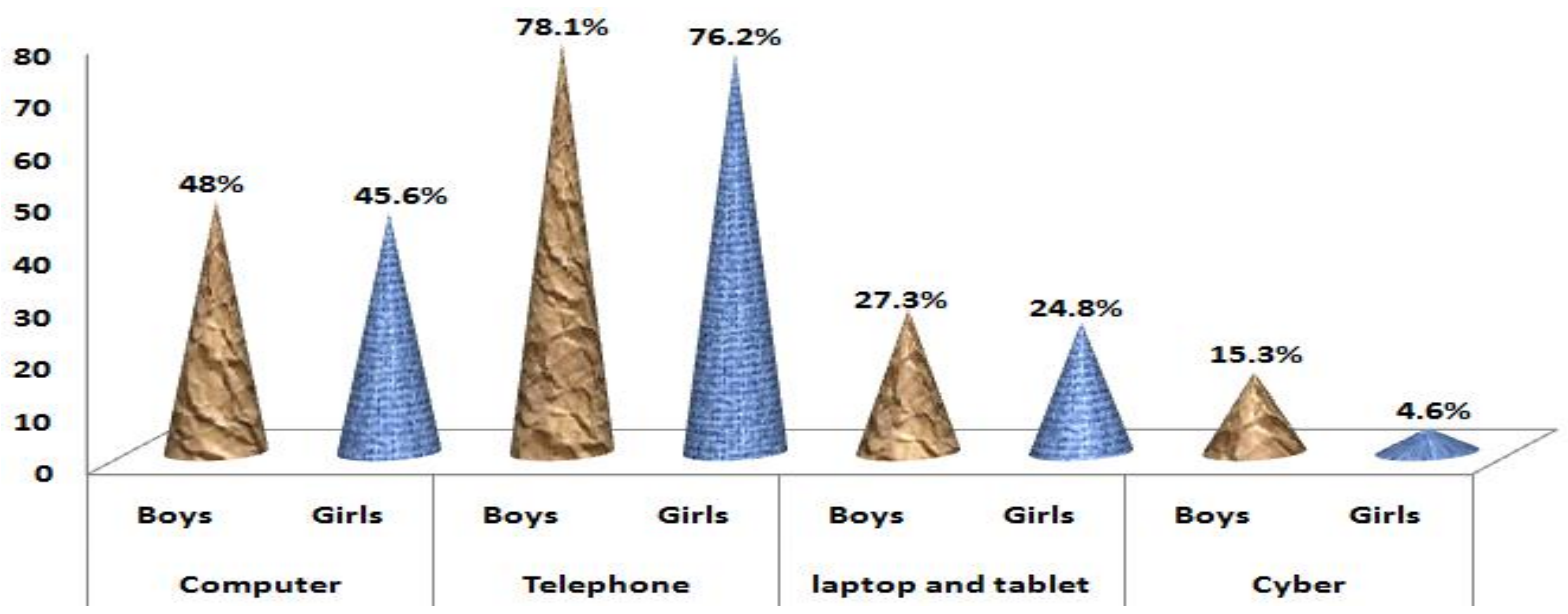

Figure (1): Distribution of the studied students regarding accessibility of social media 
Table (4): Distribution of the studied students regarding patterns of using social media

\begin{tabular}{|c|c|c|c|c|c|}
\hline \multirow{3}{*}{ Patterns of using social media } & \multicolumn{4}{|c|}{$\begin{array}{l}\text { The studied students } \\
(n=1000)\end{array}$} & \multirow{3}{*}{$\begin{array}{l}\chi^{2} \\
\mathbf{P}\end{array}$} \\
\hline & \multicolumn{2}{|c|}{$\begin{array}{l}\text { Boys } \\
(\mathrm{N}=483)\end{array}$} & \multicolumn{2}{|c|}{$\begin{array}{l}\text { Girls } \\
(\mathrm{N}=517)\end{array}$} & \\
\hline & No. & $\%$ & No. & $\%$ & \\
\hline $\begin{array}{l}\text { Starting to use social media for first time } \\
\text { - } \text { Since }<1 \text { year } \\
\text { - } 1-2 \text { years } \\
\text { - } 2-3 \text { years } \\
\text { - }>3 \text { years }\end{array}$ & $\begin{array}{l}86 \\
69 \\
81 \\
247\end{array}$ & $\begin{array}{l}17.8 \\
14.3 \\
16.8 \\
51.1\end{array}$ & $\begin{array}{l}94 \\
80 \\
60 \\
283\end{array}$ & $\begin{array}{l}18.2 \\
15.5 \\
11.6 \\
54.7\end{array}$ & $\begin{array}{l}5.591 \\
0.133\end{array}$ \\
\hline $\begin{array}{l}\text { Ability of using social media without help } \\
\text { - Don't use it } \\
\text { - Poor } \\
\text { - Fair } \\
\text { - Good } \\
\text { - Excellent }\end{array}$ & $\begin{array}{l}18 \\
32 \\
68 \\
156 \\
209\end{array}$ & $\begin{array}{l}3.7 \\
6.6 \\
14.1 \\
32.3 \\
43.3\end{array}$ & $\begin{array}{l}7 \\
32 \\
86 \\
161 \\
231\end{array}$ & $\begin{array}{l}1.4 \\
6.2 \\
16.6 \\
31.1 \\
44.7\end{array}$ & $\begin{array}{l}6.975 \\
0.137\end{array}$ \\
\hline $\begin{array}{l}\text { Frequency of using social media / day } \\
\text { - } 1-3 \text { times } \\
\text { - } 3-5 \text { times } \\
\text { - }>5 \text { times }\end{array}$ & $\begin{array}{l}255 \\
112 \\
116\end{array}$ & $\begin{array}{l}52.8 \\
23.2 \\
24.0\end{array}$ & $\begin{array}{l}314 \\
97 \\
106\end{array}$ & $\begin{array}{l}60.7 \\
18.8 \\
20.5\end{array}$ & $\begin{array}{l}6.496 \\
0.039 *\end{array}$ \\
\hline $\begin{array}{l}\text { Duration of spending / session } \\
\text { - } \quad<5 \text { minutes } \\
\text { - } 5-15 \text { minutes } \\
\text { - } 15-30 \text { minutes } \\
\text { - } 30-60 \text { minutes } \\
\text { - } 1-2 \text { hours } \\
\text { - }>2 \text { hours }\end{array}$ & $\begin{array}{l}74 \\
109 \\
66 \\
96 \\
81 \\
57\end{array}$ & $\begin{array}{l}15.3 \\
22.6 \\
13.7 \\
19.9 \\
16.8 \\
11.8\end{array}$ & $\begin{array}{l}53 \\
123 \\
101 \\
66 \\
83 \\
91\end{array}$ & $\begin{array}{l}10.3 \\
23.8 \\
19.5 \\
12.8 \\
16.1 \\
17.6\end{array}$ & $\begin{array}{l}23.915 \\
<0.01 * *\end{array}$ \\
\hline
\end{tabular}

* Significant at $\mathrm{P}<0.05$

$* *$ Significant at $\mathrm{P}<0.01$. 
Table (5): Distribution of the studied students regarding their parents' oversight on using social media by them

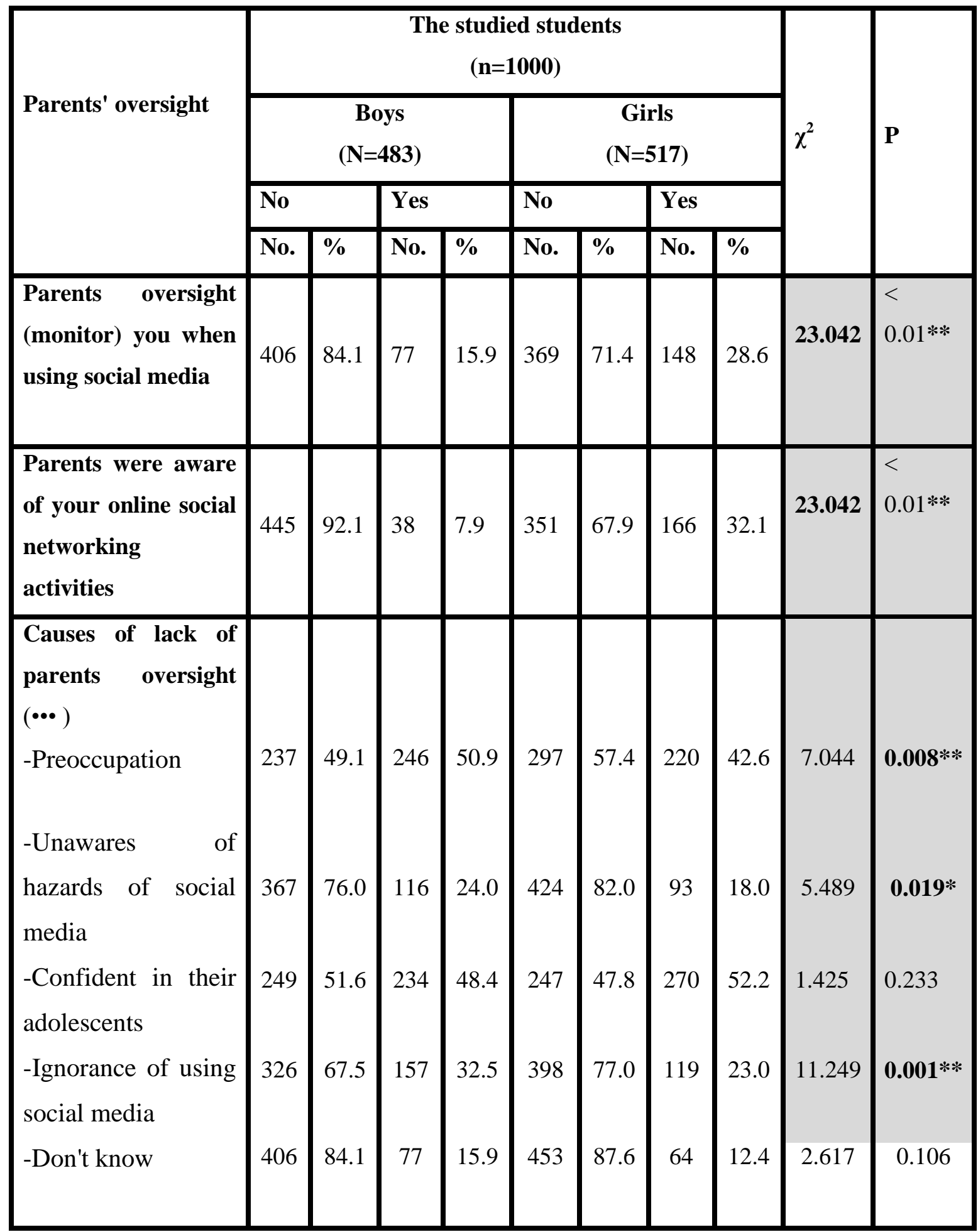

* Significant at $\mathrm{P}<0.05 \quad * *$ Significant at $\mathrm{P}<0.01 \quad \cdots$ More than one response 
Table (6): Correlation between socio-demographic data of the studied students and their parents and their patterns of using social media

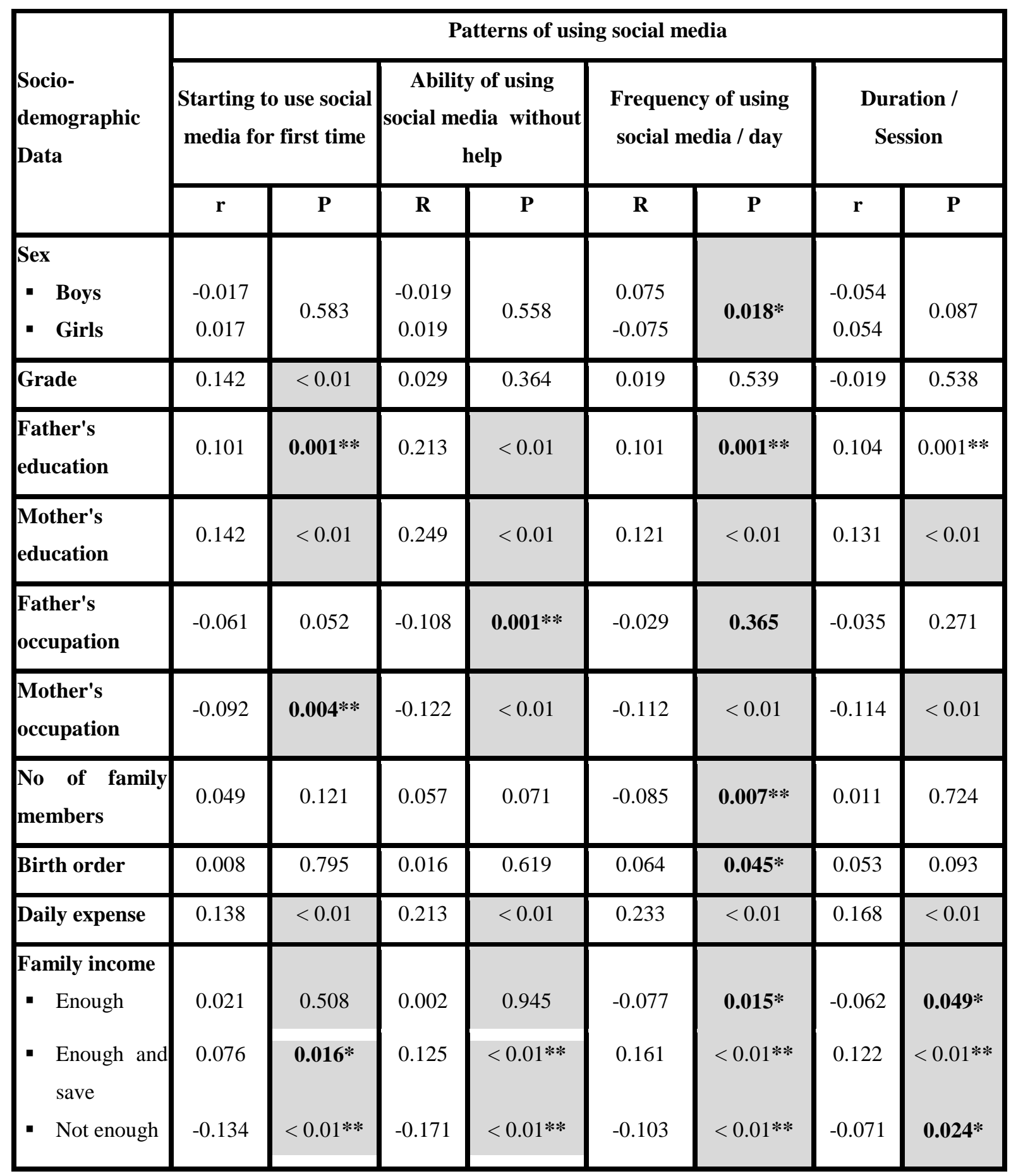

* Significant at $\mathrm{P}<0.05$.

** Significant at $\mathrm{P}<0.01$. 


\section{Discussion}

Social media have benefits when used for education, information and access healthpromotion messages. However, social media have also a lot of health hazards due to inaccurate, inappropriate or unsafe content and contacts. Parents face challenges in oversight their adolescents' use and in serving as positive role models (29). Therefore, the aim of this study was to assess perception of adolescent students regarding different health hazards of social media.

The present study showed that the majority of studied boys and girls were living with their parents and siblings. This result is in the same line of the study done by Shaheen et al. (2016) ${ }^{(30)}$, who revealed that the majority of school students lived with their parents at home.

Concerning studied students parents' education, the results of the present study showed that, more than one third of both of them their parents had secondary and university education. Furthermore, the result showed that there were highly positive correlation between fathers' and mothers' education and students patterns of using social media. This result is in agreement with the study done by Desouky and Ibrahem (2015) ${ }^{(31)}$, who found that, two fifths of subjects' parents had secondary education.
Also, this result of current study is in agreement with the study of Ahmadi et al. (2014) ${ }^{(32)}$, about internet addiction among Iranian adolescents who reported that, nearly half of his participants' parents had a high education with a significant difference between the three types of net users (addicts, potential addicts and nonaddicts) and their parents' education. This agreement may be due to the important of parents' education which make them more confident in setting the rules and aware of hazards of social media so can influence on their adolescents ' behaviors.

With no doubt, high and optimal family income help students to use social media through the availability of different sources. In this regard, the present study illustrated that, nearly two thirds of studied boys and girls had enough family income. This is in accordance with the result of Shaheen et al. (2016) ${ }^{(30)}$, who stated that nearly half of the students were of middle socioeconomic level and one quarter of them were of high socioeconomic level. Also, Saied et al. (2016) ${ }^{(33)}$, showed that more than one half of both Egyptian and Malaysian students were had enough family income and can save it.

The present study showed that, social media was accessible for more than three quarters of both boys and girls through mobile phones while less than half of them 
access it through computers and about one quarter of both of them access social media through laptops or tablets (table 4). This is in agreement with the result of the study done by Saied et al. (2016) ${ }^{(33)}$, who study internet and Facebook addiction among Egyptian and Malaysian medical students. They stated that, the majority of both of them had internet access especially through mobile phone and laptop. On the other hand, the current study revealed that less than one fifth of the studied boys compared to only $4.6 \%$ of studied girls access social media through cyber or net café. Which is contradicted with Saied et al. (2016) ${ }^{(33)}$, who found that half of subjects access the internet through net café. This difference may be related to that most of students in secondary school in Tanta city were from around villages in which there wasn't available net café.

In the same line, the study done by Shaheen et al. (2016) ${ }^{(30)}$ revealed that, all of studied sample had computers, two thirds of them had private laptops and most of them had mobiles and internet access at their homes. This attributed to the fact that the mobiles more accessible and available for all ages at any time and any place especially away from their parents supervision.

Adolescents usage of social media has a lot of goals. Results of the present study indicates that, the majority of studied boys and girls used social media for communication with relatives /friends. Also, more than half and about two fifths of both of them used the social media for learning / search and for share photos / entertainment.

This result goes in the same line with Chowdhury et al. (2015) (34), who reported that the main cause for using the computer and the internet by youth was for chatting with their friends for a prolong time without benefits. Also, this result go in the same line with the study done by Saied et al. (2016) ${ }^{(33)}$, who showed that, the majority of both Egyptian and Malaysian students reported that they use Facebook to keep in touch with friends \& relatives and for studying issues. This is because of the adolescents and young people period needs for identity development and their susceptibility to peer influence and change of social interaction.

Unfortunately, the age of start and duration of using social media sources can affect the occurrence of health hazards that associated with social media use. Also, the study done by Desouky and Ibrahem (2015) ${ }^{(31)}$, reported that, the significant correlation between General Health Questionnaire (GHQ) scores “experienced severe problems and psychological distress "and young internet addiction test (YIAT) 
for those who spent more than 4hours /day and more than 6 times weekly.

The result of present study revealed that more than half of the studied boys and girls had starting to use social media for first time since more than three years. This finding is in agreement with the study done by Jafarkarimi and Saadatdoost (2016) (35), who showed that, half of students had starting to use social media for first time since $\geq 4$ years and two fifths of them had starting to use it for first time since < 4years. While, Saied et al. (2016) ${ }^{(33)}$, showed that, the majority of Egyptian and Malaysian students had starting to use social media since $>5$ years. This is because he studied university students while the present study studied secondary students who are in early age group.

Regarding to the duration of each media contact, the present study illustrated that one fifth of boys and girls spent $>2$ hours using social media / session. This result is in agreement with the study done by Jafarkarimi and Saadatdoost (2016) ${ }^{(35)}$, who showed that, more than half of the students younger than 20 years old were addict social media use while about one half of them use social media 1-3 hours/ day.

This result also is agreement with Jamaluddin and Jeyakumar (2012) ${ }^{(36)}$, who showed that nearly three quarters of respondents can be considered as SNS addict who spent at least 5-8 hours daily. Also, most of them login to SNS daily and spent at least three hours every login. This may be explained as this adolescence period is a time to make outside relationships in which they using social media to explore outside world.

Effective parenting is a solution to monitor their adolescents' social media activities and help them think about online presence in moral and ethical ways. Parents have wide range of actions to monitor their teen's online as speaking with their teen about acceptable and unacceptable online behavior as well as checking up their teen websites, taking a proactive approach to prevent problems and using parental tools to monitor or block online content $(37,38)$. The study done by Martha (2012) (37), revealed that, only online safety measures weren't adequate in protecting adolescents online but a combination of parental oversight, education, enlightenment and service providers policies help to reduce online risks.

However, the present study revealed that the majority of studied boys and girls reported that their parents didn't oversight them, while using social media and that they are not aware of their social media activities. Concerning the causes of lack of parents' oversight, about half of the studied boys and girls perceived that, this may be due to the parents' preoccupation and 
parents' confidence in their adolescents. This results is in the same line with the result of study done by EI Gazzar (2013) (39), who reported that the majority of adolescents stated that their parents do not set any rules regarding their internet usage and the adolescents just ignoring the whole experience when facing risks.

However, these results are in contrast with the result of Moawad and Ebrahem (2016) $^{(40)}$, who stated that most of adolescents reported that, their parents give them enough amount of oversight, observing and give them advices about their way of using mobile or internet and their parents dealing with them as a responsible person. Also, a national survey of Anderson (2016) ${ }^{(41)}$, showed that, parents of teens ages 13 to 17, in 2014 and 2015 in United states (U.S.) reported that most parents check their teens online; $61 \%$ have ever checked their teen's social media profiles; $56 \%$ have ever friended or followed their teen on Facebook or other social media platform; nearly half of parents know their teen's email password and $39 \%$ of them using parental controls for blocking or oversight their teen's online activities.

This difference may be due to the lack of parents' awareness of social media hazards and parents preoccupation with life burden and related to culture difference. Overall despite parents' concerns about their teen's online activities, parents may not know much about them and not effective at setting limits and oversight their activities that may be due to increasing smart phones, parents' lack of knowledge about these websites and adolescents think that sharing their personal experiences to their parents may be less acceptable. In addition, lack of parenting skills as communication including listening, availability, mutual respect, acceptance and understanding their behavior and their problems may also effecting factors.

The results of the present study revealed that there was a significant relationship between parents' education and the students' patterns of use to different social media. This result is in line with the study done by Mazaheri et al. (2014) ${ }^{(42)}$, who revealed that, highly educated parents tend to socialize their adolescents into the modern information technology world.

The present study presented that all items of patterns of using social media increases with enough and save family income. On the other hand, all items of patterns of using social media decreases with family haven't enough income. This finding is disagreement with the study done by $\mathbf{N a z}$ et al. (2011) (43), who showed that smartphone use has been increasing in all economic and age sectors. Modernism and technological advancement provide the opportunities for individual's income and 
economic position as the technology excessive uses which adversely influences the economic structure. Also, the study done by Martha (2012) ${ }^{(37)}$, revealed that, the income was not a factor in internet oversight. This disagreement may due to parents with higher incomes and more skillful with the internet would be more set rules regarding internet use than parents with lower socioeconomic and limited skills.

The present study revealed presence of a significant correlation between students' sex and the frequency of using social media / day. Studied boys are more frequent of using social media / day than girls. This result is disagreement with the study done by Gorkemli (2017) ${ }^{(44)}$, who stated that, no significant relation between students' sex and internet usage. While, the study done by Kuss et al. (2012) ${ }^{(45)}$, stated that the males are more susceptible to internet addiction than females. This finding is in agreement with study done by Salehi et al. (2014) ${ }^{(46)}$, who revealed that boys students reported problematic internet use more than girls.

These results may be explained as female students in eastern cultures have more parental supervision than males so, they haven't much time to use the internet than boys. In addition, the nature of secondary school education may be a barrier towards having enough time to a degree of internet addiction. Moreover, gender is an important factor in the adoption of technology that male tend to more highly usefulness of technology while, females tend to ease of use it.

At the end we can see that our adolescents can't see the whole picture about the nature of social media and internet usage and focus only on their benefits. They need more orientation and health educational messages to target this aspect.

\section{Conclusion}

At the end of this study, it can be concluded that the telephone was the most available method for studied students to access social media. The majority of them use social media for communication since more than three years $s$ for about 3 times per day. Lack of parental oversight (monitoring) was prevalent among the studied subjects while using social media. Moreover, most of males and two thirds of females reported that their parents were not aware of their online social networking activities. Preoccupation was reported as a cause for lack of parental oversight from about half of the studied adolescents.

\section{Recommendations}

So the study recommended that health educational programs should be designed and directed to preparatory and secondary school students to improve inappropriate use of social media to prevent its hazards. Educate the parents and the families about 
the importance of their oversight and follow up to their adolescents during using social media. Also, emphasizing the role of parents in discussing the hazards of social media and internet with their adolescents and improve their self-esteem and self-acceptance rather seeking approval from others through these sites is essential. Moreover, emphasizing the role of school health visitor in increasing awareness of adolescent students about different hazards of social media and internet. Further researches is required to investigate factors associated with excessive uses of social media especially psychological and social factors.

\section{References}

1. Crosnoe R, Johnson M. Research on adolescence in the Twenty-First century. Annual Review of Sociology. 2013; 37(1):439-460.

2. Index Mundi. Egypt Demographics Profile 2018 - Index Mundi, 2018. Available at: https://www.indexmundi. com/egypt/demographics_profile.html

3. Simuforosa M. The impact of modern technology on the educational attainment of adolescents. International Journal of Education and Research. 2013; 1 (9): 1-8.

4. Mullan K. Technology and children's screen-based activities in the UK: The story of the millennium so far. Child Indicat. Res. 2018; 11 (6): 1781-1800.
5. Sylvia M, Lee $\mathrm{S}$.User perceptions of social media: A comparative study of perceived characteristics and user profiles by social media. Online Journal of Communication and Media Technologies. 2013; 3(4):149-178.

6. Liu D, Baumeister R. Social networking online and personality of self-worth: A meta-analysis. Journal of Research in Personality. 2016; 64(1): 79-89.

7. Cramer S, Inkster B. Status of mind: Social media and young people's mental health and wellbeing. (Report.) London, England: Royal Society for Public Health (UK) and Young Health Movement (UK). 2017. Available at https://www.rsph.org.uk/static/uploade $\mathrm{d} / \mathrm{d} 125 \mathrm{~b} 27 \mathrm{c}-0 \mathrm{~b} 62-41 \mathrm{c} 5-$ a2c0155a8887cd01.pdf.

8. Jelenchick L, Eickhoff J, Zhang C, Kraninger K, Christakis D, Moreno M. Screening for adolescent problematic Internet use: Validation of the Problematic and Risky Internet Use Screening Scale (PRIUSS). Acad. Pediatr. 2015; 15(6):658-665.

9. Arab Social Media Influencers Summit. Arab Social Media Report WPP. Com, $1^{\text {st }}$ report. 2015. Available at:https://www.wpp.com/ govtpractice/media/wppgov/arabsocial mediareport-2015 
10. Mourtada R, Salem F. Arab Social Media Report: Civil Movements: The Impact of Facebook and Twitter. Dubai School of Government. 2011;1(2):1-30.

11. Attia M B. Impact of Facebook on Egyptian youth culture identity Lecturer of Radio and TV, Media Department. College of Language \& Communication. Alexandria. Arab Academy for Science. Technology and Maritime Transport. 2018 (6): 1-28.

12. Roushdy R. Summary report: Panel survey of young people in Egypt 2014 generating evidence for policy, programs and research. Cairo: Population Council. 2015:1-13. Available at: www.popcouncil.org/ .../survey-of-young-people-in-egy...

13. Digital 2020: Egypt- Data Reportal Glopal Digital Insight. Available at: https://datareportal.com/reports/digital -2020-egypt

14. Khalil S A, Kamal H, Elkholy H. The prevalence of problematic Internet use among a sample of Egyptian adolescents and its Psychiatric Comorbidities. Int. J. Soc. Psychiatry. 2020 Dec; Doi: $10.1177 / 0020764020983841$

15. Outback treatment (program of internet addiction). The Dangers of Social Media for Teens. 2020. Available at:https://www.outback treatment.com/the-dangers-of-socialmedia-for-teens/

16. Durbin J, Cristina R, Lundeen $\mathrm{H}$. Social media and adolescents: What are the health risks? June 8, 2018. Available at: https://www.clinical advisor.com/home/features/socialmedia-and-adolescents-what-are-thehealth-risks/

17. Vaala S E, Bleakley A. Monitoring, mediating, and modeling: Parental influence on adolescent computer and Internet use in the United States. Journal of Children and Media. 2015; 9 (1): 40-57. Published online: 07 Jan 2015.://www.tandfonline.com/doi/abs/ 10.1080/17482798.2015.997103

18. Ben-Joseph E P. Monitoring your child's media use. 2019. Available from https://kidshealth.org/en/parents/ monitor-media.html

19. Mintz S, aka Ethics Sage. Parents Monitor their Teens Social Media Activities - Ethics. Feb 19, 2019. Available from: https://www. ethicssage.com/2019/02/shouldparents-monitor-teens-social-mediaactivities.html.

20. Tejedor S, Pulido C. Challenges and risks of Internet use by children. How to Empow-er Minors? Comunicar. 2012; 39 (XX):65-72.

21. Viero V, Farias J, Ferraz F, Simoes P, Martins J. Educacao em Saude com 
Adolescentes: Analise da Aquisicao.de Conhecimentos Sobre Temas de Saude. Esc Anna Nery Rev Enferm. 2015; 19(3):484-90. [cited 2016 Oct 10]Available at: https://www.scielo. br/j/ean/a/wyHpK9Nm4p4wjjp7sHKb $\mathrm{kLw} /$ ?format $=\mathrm{pdf} \&$ lang $=\mathrm{pt}$

22. Hanninen O, Knol A, Conrad A. Environmental burden of disease in Europe: Assessing nine risk factors in six countries. Environ Health Perspect. 2014; 122(5):439-46.

23. Culture and Youth. Review: Stop Cyber bullying before it starts Culture and Youth. 2014. Available at: cultureandyouth.org/.../articles.../revie w-stop-cyberbullying-starts

24. Help Guide. Dealing with Cyberbullying: Tips for kids and parents to prevent and abuse. Help guide, 2016. Available from: www. helpguide.org/articles/abuse/cyberbull ying.htm

25. Kirik A, Arslan A. A quantitative research on the level of social media addiction among young people in Turkey. International Journal of Science Culture and Sport (IntJSCS). 2015; 3(3):108-122.

26. Kaya T, Bicen H. The effects of social media on students' behaviors: Facebook as a case study. Computers in Human Behavior. 2016; 59(C): 374-379.
27. Albarashdi H, Bouazza A, Jabur N, Al-Zubaidi A. Smartphone addiction reasons and solutions from the perspective of Sultan Qaboos University Undergraduates: A Qualitative Study. Int. J. Psychol. Behav. Anal. 2016; 113 (2):1-10.

28. Abraham A. Sexting Uncensored: An Exploratory Study on the Behaviors, Experiences and Perceptions of Sexting among College Students. Published Master Thesis of Public Health. College of Health and Human Services. California State University. 2015:1-100. Available at: https://www.researchgate.net/profile/A nju_Abraham4/publication/281652117 _Sexting_Uncensored_An_Explorator y_study_on_the_Behaviors_Experienc es_and_Perceptions_of_Sexting_amon g_College_Students/links/55f32a6608 ae63926cf2352b.pdf

29. Reda M, Rabie M, Mohsen N, Hassan A. Problematic Internet users and psychiatric morbidity in a sample of Egyptian adolescents. Psychology. 2012; 3(8): 626-31.

30. Shaheen H, Farahat T, Gaber H. Problematic Internet use among medical school students. Department of Family Medicine, Menoufia University Faculty of Medicine, Egypt. J. Child Adolesc. Behav. 2016; 4(3): 2375-94. 
31. Desouky D, Ibrahem $\mathrm{R}$.Internet addiction and psychological morbidity among Menoufia University Students, Egypt. American Journal of Public Health Research. 2015; 3(5):192-8.

32. Ahmadi K. Internet addiction among Iranian adolescents: A Nationwide study. Acta Med Iran. 2014; 52(6): 467-472.

33. Saied S, Elsabagh H, El-Afandy A. Internet and Facebook addiction among Egyptian and Malaysian medical students: A comparative study. Tanta University, Egypt International Journal of Community Medicine and Public Health. Int. J Community Med Public Health. 2016; 3(5):1288 -1297.

34. Chowdhury D, Roy I, Biswajeet S. Impact of Facebook as a Social Networking Site (SNS) on youth generations: A case study of Kolkata City. International Journal of Humanities and Social Science Invention ISSN. 2015; 4 (6): 28-42.

35. Jafarkarimi $H, \quad$ Saadatdoost $R$. Facebook addiction among Malaysian Students. International Journal of Information and Education Technology. 2016; 6(6): 465-469.

36. Jamaluddin $H$, Jeyakumar R. Determinants and prevalence of Social Networking addiction among Varsity Students in Malaysia. Faculty of
Business and Law, Multimedia University. 2012:1-8. Available at: https://www.researchgate.net/publicati on/270740671_Determinants_and_pre valence_of_Social_Networking_addict ion_among_varsity_students_in_Malaysia

37. Martha S. Parents' perceptions of the influence of Social Media Networking on the children of Demonstration. Master thesis in Mass Communication. Secondary School, Ahmadu Bello University, Zaria. 2012:1-99. Available at: https://journals.sagepub. com/doi/full/10.1177/0042085915623334

38. Toombs E. Evaluating the Parent Adolescent Communication Toolkit: Usability, MeKirik A, Arslan A. A Quantitative research on the level of social media addiction among young people in Turkey. International Journal of Science Culture and Sport (IntJSCS). 2015; 3(3):108-122.

39. El Gazzar N. The role of social media networks in enhancing political change amongst adolescents in Egypt: A survey. Misr International University. Stirling International Journal of Postgraduate Research. 2013;1 (2) :1-11.

40. Moawad G, Ebrahem G. The relationship between use of technology and parent-adolescents social relationship. Journal of 
Education and Practice. 2016; among medical students from 7(14):170-178. Mashhad, Iran in 2013. Iran Red

41. Anderson M. Parents, Teens and Crescent Med J. 2014; 16(5): e17256.

Digital Monitoring-Pew Internet, 2016. Available from: www. pewinternet.org/PI_2016-01-07_ Parents-Teens-Digital-monitoring .FINAL. p.

42. Mazaheri M, Mohamed F, Karbasi M. Mobile Phone usage patterns among students in Iran. Reef Resources Assessment and Management Technical Paper. 2014; 40(1): 313-319.

43. Naz A, Khan W, Daraz U, Hussain M. The malevolence of technology: An investigation into the various socioeconomic impacts of excessive Cell Phone use among University Students (A Case Study of University of). International Journal of Academic Research in Business and Social Sciences. 2011; 1(3): 2222-6990.

44. Gorkemli N. Internet and Social Media usage of secondary school students in rural areas. Manas. Journal of Social Studies. 2017; 6(1): 1-11.

45. Kuss D, Griffiths M. Internet gaming addiction: A systematic review of empirical research. International Journal of Mental Health and Addiction. 2012; 10(2): 278-96.

46. Salehi M, Khalili M, Hojjat S, Saleh M, Danesh A. Prevalence of Internet addiction and associated factors 